\title{
Mitgliederversammlung der DEGUM
}

\section{Tagesordnung}

TOP 1 Annahme der Tagesordnung

TOP 2 Annahme des Protokolls der Mitgliederversammlung bei dem Dreiländertreffen am 30.10.14 in Innsbruck

TOP 3 Bericht des Vorstands

TOP 4 Bericht des Schatzmeisters

TOP 5 Entlastung des Vorstands

TOP 6 Aufnahme neuer Mitglieder

TOP 7 Ehrungen

> Preise (Wissenschaft und Promotion)

- Ehrenmitgliedschaften

TOP 8 Berichte aus den Sektionen und Arbeitskreisen

TOP 9 Verschiedenes

Prof. Dr. med. D. Becker, Präsident Prof. Dr. med. P. Jecker, Sekretär 